\title{
UI AKURASI PRODUK REFLEKTAN PERMUKAAN LANDSAT-8 BESERTA PENGARUHNYA TERHADAP PENENTUAN KONSENTRASI SUSPENDED SOLID (STUDI KASUS:DANAU KASUMIGAURA, JEPANG)
}

\author{
Lalu Muhamad Jaelani ${ }^{1}$, Erika Yuniar Tyastiti ${ }^{2}$ \\ 1,2Departemen Teknik Geomatika FTSLK-ITS, Kampus ITS Sukolilo, Surabaya, 60111 \\ e-mail: ${ }^{1}$ Imjaelani@geodesy.its.ac.id, ${ }^{2}$ erykayuniar80@gmail.com
}

\begin{abstract}
Abstrak
Koreksi atmosfer merupakan proses yang sangat penting karena efek atmosfer mampu mempengaruhi gelombang elektromagnetik dari matahari ke objek dan dari objek ke sensor yang menyebabkan terjadinya kesalahan pada data citra. Salah satu metode koreksi atmosfer yang sering digunakan adalah metode 6SV (Second Simulation of the Sensor Signal in the Solar Spectrum-Vector). Landsat-8 adalah citra satelit yang sering dimanfaatkan karena kemudahan perolehan data yang gratis. Pada tahun 2014, USGS mengeluarkan produk level tinggi untuk surface reflectance (Reflectance-BOA). Dengan keluarnya produk ini, maka kendala koreksi atmosfer yang harus dilakukan menjadi berkurang. Namun, belum diketahui seberapa besar tingkat akurasi dari produk ini. Pada penelitian ini akan dilakukan uji akurasi dari produk Landsat- 8 surface reflectance menggunakan data in-situ Remote sensing reflectance $(\operatorname{Rrs}(\lambda))$ dan Suspended Solid (SS) yang direkam secara langsung di 5 (lima) stasiun sepanjang Danau Kasumigaura, Jepang. Sebagai perbandingan, data tersebut akan dibandingkan dengan data Landsat-8 yang dikoreksi dari efek atmosfer menggunakan parameter koreksi dari hasil simulasi menggunakan metode 6SV. Dari hasil penelitian ini, menunjukkan bahwa nilai Rrs $(\lambda)$-6SV dan $\operatorname{Rrs}(\lambda)$-L memiliki nilai yang lebih tinggi dari $\operatorname{Rrs}(\lambda)$-insitu di sepuluh stasiun. Sedangkan untuk korelasinya $\left(R^{2}\right) \operatorname{Rrs}(\lambda)$-L memiliki korelasi lebih tinggi yaitu sebesar 0,926 dibandingkan dengan Rrs $(\lambda)$-6SV yang hanya 0,123 . Besarnya NMAE serta RMSE yang dihasilkan Rrs $(\lambda)$-6SV dan Rrs $(\lambda)$-L ini secara berturut-turut adalah 140,262\%; 0,012 dan $140,061 \% ; 0,008$.
\end{abstract}

Kata Kunci : Koreksi Atmosfer, 6SV,Landsat-8 Surface Reflectance, SS, Rrs (( $\lambda))$

\begin{abstract}
The atmospheric correction is important process because the atmosphere affect electromagnetic waves from the sun to the object and from the object to the sensor causing errors in the imagery data. One of the most common methods of atmospheric correction is the 6SV (Second Simulation of the Sensor Signal in the Solar Spectrum-Vector). Landsat-8 is a frequently used satellite imagery due to the ease of obtaining data. On December 23, 2014, the USGS issued a high level product for surface reflectance (Reflectance-BOA). With the release of this product, the constraints of atmospheric correction must be reduced. This research will test the accuracy of Landsat-8 surface reflectance product using in-situ data of Remote sensing reflectance (Rrs $(\lambda)$ and Suspended Solid those directly recorded at 5 (five) stations along Kasumigaura Lake, Japan. In comparison, the data will be compared with Landsat-8 data corrected from atmospheric effects using correction parameters from the simulation results using the $6 \mathrm{SV}$ method. The results show that the value of Rrs ( $\lambda)-6 S V$ and $\operatorname{Rrs}(\lambda)$-SR have higher value than $\operatorname{Rrs}(\lambda)$ insitu. As for the correlation $\left(R^{2}\right) \operatorname{Rrs}(\lambda)$-SR has a higher correlation i.e. 0.926 that compared with Rrs $(\lambda)-6 S V$ which is only 0.123 . The magnitude of NMAE and RMSE produced by $\operatorname{Rrs}(\lambda)-6 S V$ and $\operatorname{Rrs}(\lambda)$-SR are $140.262 \% ; 0.012$ and $140.061 \% ; 0.008$.
\end{abstract}

Keywords : Atmospheric Correction, 6SV, Landsat-8 Surface Reflectance, SS, Rrs (( $\lambda))$ 


\section{PENDAHULUAN}

Danau Kasumigaura merupakan danau terbesar kedua di Jepang dengan luas area $167.63 \mathrm{~km}^{2}$ yang terletak di daratan Prefektur Ibaraki Selatan. Danau ini sangat dangkal karena kedalaman rata-ratanya hanya 4 meter $^{[1]}$. Untuk alasan ini, Kasumigaura berisiko tinggi mengalami polusi. Oleh karena itu, butuh suatu usaha pemantauan kualitas perairan secara efektif dan efisien. Salah satu parameter kualitas perairan yang dapat digunakan adalah suspended Solid (SS).Teknologi penginderaan jauh merupakan salah satu alat yang dapat digunakan untuk memantau kualitas perairan. Ketersediaan data spasial saat ini sangat banyak tetapi belum semua memiliki kualitas data yang baik. Data citra satelit awal yang belum diolah biasanya mengandung noise/gangguan yang ditimbulkan oleh sistem ${ }^{[2]}$. Untuk dapat menghilangkannya maka diperlukan proses koreksi atmosfer.

Koreksi atmosfer merupakan proses yang sangat penting karena efek atmosfer mampu mempengaruhi gelombang elektromagnetik dari matahari ke objek dan dari objek ke sensor yang menyebabkan terjadinya kesalahan pada data citra, dimana data citra yang diperoleh dengan data yang diingikan tidak sama ${ }^{[3]}$. Salah satu metode koreksi atmosfer yang sering digunakan adalah metode 6SV (Second Simulation of the Sensor Signal in the Solar Spectrum-Vector). Salah satu produk citra penginderaan jauh yang sering dimanfaatkan adalah Landsat-8 karena kemudahan perolehan data yang bersifat gratis. Pada tanggal 23 Desember 2014, USGS mengeluarkanproduk level tinggi untuk surface reflectance (Reflectance-BOA). Dengan keluarnya produk ini, maka kendala koreksi atmosfer yang harus dilakukan menjadi berkurang. Namun, belum diketahui seberapa besar tingkat akurasi dari produk ini.

Penelitian ini bertujuan untuk menghitung akurasi produk Landsat-8 surface reflectance menggunakan data in-situ dan membandingkan nya dengan data Landsat- 8 yang dikoreksi dari efek atmosfer menggunakan parameter koreksi dari hasil simulasi menggunakan 6SV (SR-6SV) serta melakukan analisa pengaruh produk SR-6SV dan reflektan-permukaan Landsat-8 yang dikeluarkan oleh USGS (SR-L) terhadap estimasi penentuan konsentrasi SS. Data insitu yang digunakan berupa Remote sensing reflectance $(\operatorname{Rrs}(\lambda))$ dan Suspended Solid yang direkam secara langsung di 5 (lima) stasiun sepanjang Danau Kasumigaura, Jepang. Dari hasil penelitian diharapkan dapat memberikan suatu informasi mengenai tingkat keakuratan produk Landsat-8 surface reflectance yang dikeluarkan oleh USGS, sehingga dapat dijadikan acuan oleh para pengguna produk iniagar dapat meminimalisir kesalahankesalahan yang biasanya terjadi akibat dari proses koreksi atmosfer yang tidak sempurna.

\section{METODOLOGI PENELITIAN}

\section{Lokasi Penelitian}

Secara geografis Danau Kasumigaura berada pada $35^{\circ} 57^{\prime} 3,30^{\prime \prime}$ - 36 $9^{\prime} 40,67^{\prime \prime}$ LU dan $140^{\circ} 11^{\prime} 52,06^{\prime \prime}-140^{\circ} 12^{\prime} 10^{\prime \prime}$ BT. Danau ini merupakan danau terbesar kedua di Jepang dengan luas area $167.63 \mathrm{~km}^{2}$ yang terletak di dataran Prefektur Ibaraki selatan. Berikut merupakan gambar lokasi penelitian :

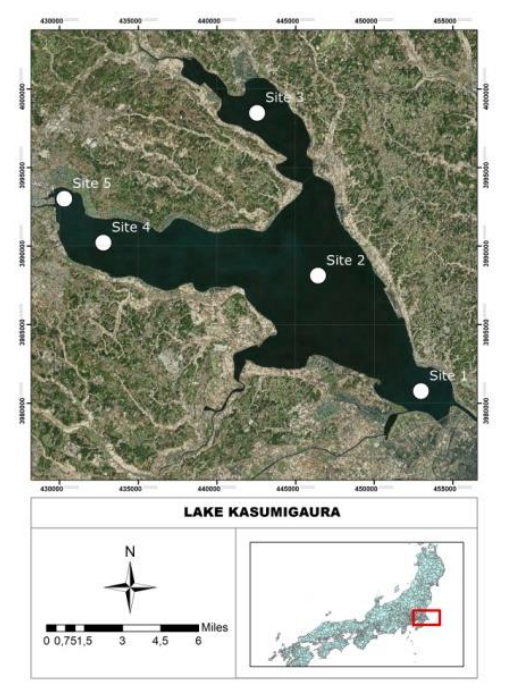

Gambar 1.Lokasi Penelitian (Landsat-8 2018)

\section{Data dan Peralatan}

\section{- Data}

Data yang digunakan dalam penelitian ini adalah:

a. Citra satelit Landsat-8 Level $1 \mathrm{~T} 12$ Maret 2014 dan 27 Oktober 2016. 
b. Landsat-8 surface reflectance 12 Maret 2014 dan 27 Oktober 2016.

c. Data in-situ Remote sensing reflectance $(\operatorname{Rrs}(\lambda))$ dan Suspended Solid Danau Kasumigaura, Jepang.

d. Data Batas Administrasi Kota di Jepang.

- Peralatan

Peralatan yang digunakan dalam penelitian ini berupa perangkat lunak yang meliputi:
a. BEAM-VISAT 5.0
b. Sentinel Application Platform (SNAP) 5.0
c. ArcGIS 10.5 .1
d. 6SV (Second Simulation of the Sensor Signal in the Solar Spectrum-Vector)

\section{Tahap Pengolahan Data}

Adapun tahapan pengolahan data sebagai berikut:

a. Kalibrasi radiometrik untuk merubah format data dari digital number ke radian atau reflektan. Data yang diproses pada tahap ini adalah citra satelit Landsat-8 level 1T (L1T).

b. Dibagi dengan bilangan 10.000 untuk mengembalikan nilai asli dari citra yang semula disimpan dalam format double float. Data yang diproses pada tahap ini adalah citra satelit Landsat-8 surface reflectance.

c. Koreksi atmosfer dengan metode 6SV (Second Simulation of the Sensor Signal in the Sensor Spectrum-vector) dilakukan untuk menghilangkan efek atmosfer, sekaligus merubah format data dari Reflektan TOA menjadi Reflektan BOA. Dari proses ini dapat menghasilkan produk reflektan-permukaan Landsat-8 (SR-6SV).

d. Membagi dengan bilangan pi $(\pi)$ agar data reflektan-permukaan Landsat-8 dari USGS (SR-L) bersama dengan data reflektanpermukaan Landsat-8 (SR-6SV) menghasilkan nilai Rrs (dalam satuan $\mathrm{sr}^{-1}$ ) sehingga memiliki satuan yang sama dengan data in situ.

e. Uji statistik nilai $\operatorname{Rrs}(\lambda)$ menggunakan fungsi koefisien korelasi ( $r$ ) untuk melihat keeratan hubungan linier antara ketiga data $\operatorname{Rrs}(\lambda)$ yang digunakan serta perhitungan
RMSE dan NMAE. RMSE dilakukan untuk melihat seberapa besar error atau kesalahan yang terjadi selama proses pengolahan data. Sedangkan NMAE digunakan untuk melihat tingkat kualitas atau kelayakan data. Jika nilai NMAE $\leq 30 \%$ maka data yang di uji dinyatakan layakuntuk digunakan untuk mengekstrak nilai SS.

$$
\begin{aligned}
& R M S E=\sqrt{\frac{\sum_{i=1}^{N}\left(X_{\text {est } i, i}-X_{\text {meas }, i}\right)^{2}}{N}} \\
& \operatorname{NMAE}(\%)=\frac{1}{N} \sum_{i=1}^{N}\left|\frac{X_{\text {esti } i}-X_{\text {meas }, i}}{X_{\text {meas }}}\right| \times 100
\end{aligned}
$$

Ekstraksi kandungan SS menggunakan algorima model dari Jaelani (2016) yang di sesuaikan dengan kondisi lokasi penelitian yang digunakan. Kemudian dilakukan ekstraksi $3 \times 3$ pixel di setiap stasiun pengamatan sesuai dengan lokasi data insitu. Ukuran $3 \times 3$ pixel digunakan untuk menghindari kemungkinan kesalahan akibat koreksi geometrik dan dinamika dari badan air, serta kesalahan akibat variabilitas spasial.

\begin{tabular}{|c|c|c|c|}
\hline \multicolumn{4}{|c|}{12 Maret 2014} \\
\hline Band & $X_{a}$ & $X_{b}$ & $X_{c}$ \\
\hline 1 & 0,003 & 0198 & 0,236 \\
\hline 2 & 0,003 & 0,143 & 0,203 \\
\hline 3 & 0,003 & 0,084 & 0,157 \\
\hline 4 & 0,003 & 0,055 & 0,129 \\
\hline \multicolumn{4}{|c|}{27 Oktober 2016} \\
\hline Band & $X_{a}$ & $X_{b}$ & $X_{c}$ \\
\hline 1 & 0,004 & 0,219 & 0,237 \\
\hline 2 & 0,004 & 0,159 & 0,204 \\
\hline 3 & 0,004 & 0,095 & 0,158 \\
\hline 4 & 0,004 & 0,062 & 0,130 \\
\hline
\end{tabular}

Tabel 1. Parameter Hasil Koreksi Atmosfer

f. Menganalisa kelayakan produk reflektanpermukaan Landsat-8 yang dikeluarkan oleh USGS (SR-L) serta pengaruh produk SR$6 S V$ dan SR-L terhadap estimasi penentuan konsentrasi SS.

\section{HASIL DAN PEMBAHASAN}

\section{Validasi Remote sensing reflectance $(\operatorname{Rrs}(\lambda))$ Landsat-8}

Untuk menguji akurasi nilai $\operatorname{Rrs}(\lambda)$ yang sudah terkoreksi dari efek atmosfer baik dengan metode 6SV ( $\operatorname{Rrs}(\lambda)$-6SV) atau yang sudah 
terkoreksi langsung dari USGS ( $\operatorname{Rrs}(\lambda)$-SR) dapat dilakukan dengan mencari rata-rata nilai pixel yang diekstrak dengan ukuran $3 \times 3$ di 5 titik stasiun pengamatan yang nantinya akan dibandingkan dengan $\operatorname{Rrs}(\lambda)$ in-situ.Penerapan regresi dilakukan pada nilai $\operatorname{Rrs}(\lambda)$ hasil pengolahan citra dan nilai $\operatorname{Rrs}(\lambda)$ data insitu.

Uji korelasi ini dilakukan dengan menggunakan regresi linier sederhana yang bertujuan untuk mengetahui hubungan antara hasil pengolahan data citra dan data lapangan serta menggunakan fungsi koefisien determinasi $\left(R^{2}\right)$. Setelah diketahui nilai korelasi masing-masing $\operatorname{Rrs}(\lambda)$, maka dilakukan uji validasi untuk mengetahui apakah metode yang digunakan sesuai atau tidak. Uji validasi pada penelitian ini menggunakan metode Normalized Mean Absolute Error (NMAE) dengan toleransi absolut error sebesar $\leq 30 \%$ (Jaelani 2016) serta menggunakan Root Mean Square Error (RMSE). Berikut ini adalah tabel hasil perhitungannya:

Tabel 2. Hasil perhitungan data $\operatorname{Rrs}(\lambda)$ in-situ dengan $\operatorname{Rrs}(\lambda)$-SR

\begin{tabular}{ccccc}
\hline Stasiun & $\left.\mathbf{( R}^{\mathbf{2}}\right)$ & $\mathbf{r}$ & $\mathbf{N M A E}(\%)$ & $\mathbf{R M S E}$ \\
\hline 1A & 0,996 & 0,998 & 107,558 & 0,008 \\
2A & 0,992 & 0,996 & 130,972 & 0,010 \\
3A & 0,980 & 0,990 & 127,420 & 0,010 \\
4A & 0,996 & 0,998 & 144,872 & 0,011 \\
5A & 0,986 & 0,993 & 105,285 & 0,011 \\
1B & 0,974 & 0,987 & 111,405 & 0,004 \\
2B & 0,947 & 0,973 & 118,357 & 0,006 \\
3B & 0,913 & 0,956 & 163,409 & 0,005 \\
4B & 0,837 & 0,915 & 147,671 & 0,005 \\
5B & 0,870 & 0,933 & 243,667 & 0,008 \\
Rata-rata & 0,949 & 0,974 & 140,062 & 0,008 \\
\hline
\end{tabular}

Tabel 3. Hasil perhitungan data $\operatorname{Rrs}(\lambda)$ in-situ dengan $\operatorname{Rrs}(\lambda)-6 S V$

\begin{tabular}{ccccc}
\hline Stasiun & $\left.\mathbf{( R}^{\mathbf{2}}\right)$ & $\mathbf{r}$ & $\mathbf{N M A E}(\%)$ & $\mathbf{R M S E}$ \\
\hline 1A & 0,052 & 0,228 & 207,844 & 0,015 \\
2A & 0,065 & 0,255 & 227,237 & 0,017 \\
3A & 0,060 & 0,245 & 216,174 & 0,017 \\
4A & 0,042 & 0,205 & 240,557 & 0,018 \\
5A & 0,055 & 0,235 & 177,371 & 0,018 \\
1B & 0,823 & 0,907 & 28,565 & 0,002 \\
2B & 0,819 & 0,905 & 26,979 & 0,002 \\
3B & 0,329 & 0,574 & 60,740 & 0,003 \\
4B & 0,573 & 0,757 & 39,288 & 0,001 \\
5B & 0,545 & 0,738 & 177,870 & 0,006 \\
Rata-rata & 0,336 & 0,505 & 140,263 & 0,010 \\
\hline
\end{tabular}

Hasil rata-rata koefisien determinasi $\left(\mathrm{R}^{2}\right)$ antara $\operatorname{Rrs}(\lambda)$ in-situ dengan $\operatorname{Rrs}(\lambda)$ SRadalah sebesar 0,949yang menandakan data insitu sangat berpengaruh terhadap data estimasi sedangkan koefisien determinasi $\left(\mathrm{R}^{2}\right)$ antara $\operatorname{Rrs}(\lambda)$ in-situ dengan $\operatorname{Rrs}(\lambda)$-6SV rata-ratanyahanya sebesar 0,336 . Nilai koefisien korelasi ( $r$ ) antara $\operatorname{Rrs}(\lambda)$ in-situ dengan $\operatorname{Rrs}(\lambda)$-SRberbanding lurus dengan nilai $R^{2}$ nya yaitu 0,974 yang menandakan adanya keeratan hubungan antar kedua produk ini, sedangkan nilai korelasi antara $\operatorname{Rrs}(\lambda)$ in-situ dengan $\operatorname{Rrs}(\lambda)$-6SV hanya berkisar 0,505 . Untuk nilai rata-rata $R M S E$ dan NMAE yang dihasilkan oleh $\operatorname{Rrs}(\lambda)$ in-situ dengan $\operatorname{Rrs}(\lambda)$-SR adalah sebesar0,008 dan $140,062 \%$. Sementara RMSE dan NMAE untuk $\operatorname{Rrs}(\lambda)$ in-situ dengan $\operatorname{Rrs}(\lambda)$ 6 SV rata-ratanya sebesar 0,010 dan $140,263 \%$. Jika melihat nilai NMAE yang dihasilkan oleh $\operatorname{Rrs}(\lambda)$-6SV dan $\operatorname{Rrs}(\lambda)$-SR keduanya memiliki nilai NMAE yang cukup besar sehingga belum bisa digunakan untuk mengekstrak data kualitas air dari data penginderaan jauh karena nilai NMAE masih dibawah syarat minimum yaitu $\leq 30 \%$.

Gambar 2 menampilkan grafik perbandingan hasil antara $\operatorname{Rrs}(\lambda)-6 \mathrm{SV}, \operatorname{Rrs}(\lambda)$ SR dan $\operatorname{Rrs}(\lambda)$ in-situ pada 10 titik stasiun pengamatan. Stasiun 1A-5A merupakan data $\operatorname{Rrs}(\lambda)$ yang direkam pada Tanggal 12 Maret 2014 sedangkan stasiun 1B-5B data yang direkam pada tanggal 27 Oktober 2016. Dapat dilihat dari ke-10 grafik tersebut bahwa niliai $\operatorname{Rrs}(\lambda)$ in-situ berada di bawah kedua nilai $\operatorname{Rrs}(\lambda)$-6SV, dan $\operatorname{Rrs}(\lambda)$-SR dan ketiga nya memiliki bentuk spektral yang berbeda. Melihat data visibillity horizontal pada saat pengukuran dilapangan sebesar 9,6 hingga 9,8 $\mathrm{km}$, yang artinya kondisi atmosfer diatas Danau Kasumigaura sangat jernih pada waktu itu, maka kontribusi dari aerosol scattering pada data yang direkam oleh senseor adalah sangat kecil. Efek atmosfer pada kondisi tersebut sebagian besar berasal dari Rayleigh scattering. Namun, pada gambar dibawah menunjukkan nilai $\operatorname{Rrs}(\lambda)$ 6SV dan $\operatorname{Rrs}(\lambda)$-SR memiliki nilai yang jauh lebih tinggi dari $\operatorname{Rrs}(\lambda)$ in-situ. Hal tersebut dapat terjadi karena $\operatorname{Rrs}(\lambda)$ $6 \mathrm{SV}$ dan $\operatorname{Rrs}(\lambda)$-SR mengalami over-koreksi pada kontribusi aerosol. 


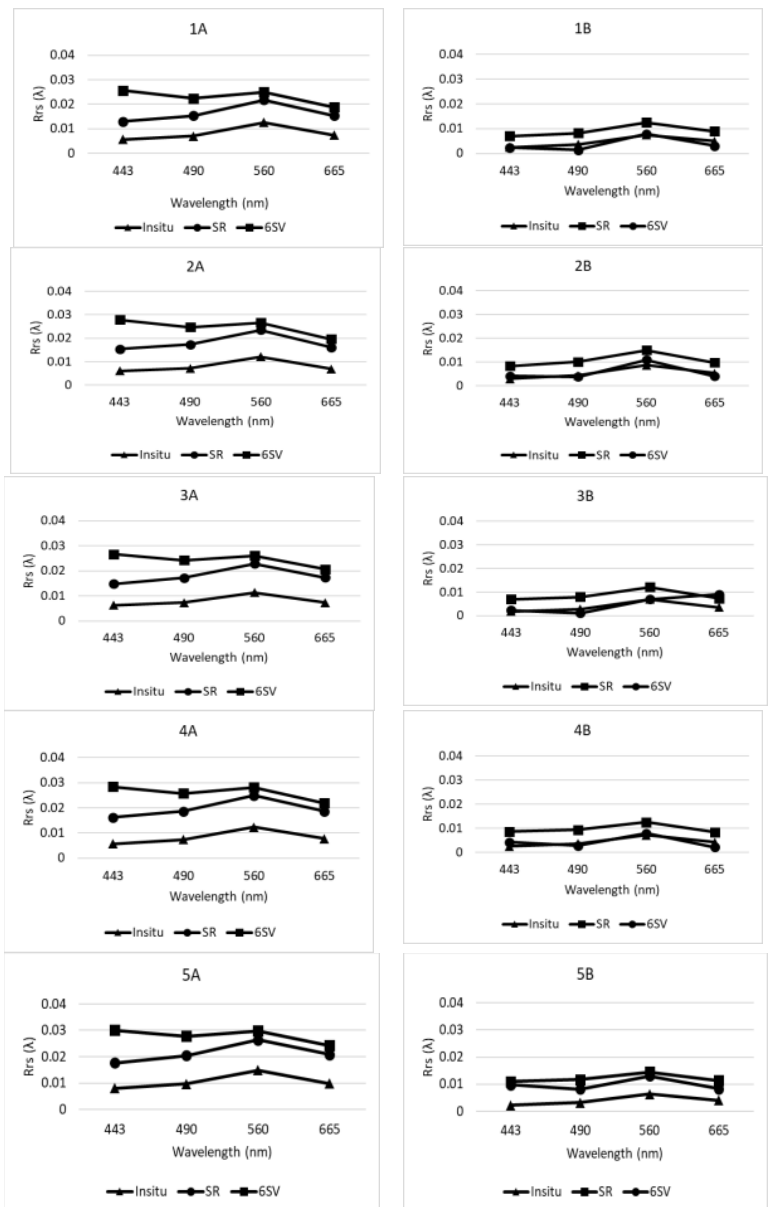

Gambar 2. Perbandingan $\operatorname{Rrs}(\lambda)$ in-situ , $\operatorname{Rrs}(\lambda)-6 S V$, $\operatorname{Rrs}(\lambda)-L$

\section{Distribusi Estimasi Suspended Solid}

Seperti yang telah diketahui bahwa nilai $\operatorname{Rrs}(\lambda)$ dari kedua data yang digunakan tidak memenuhi syarat minimum NMAE untuk dapat dilakukan ekstraksi data kualitas air dari data penginderaan jauh. Namun, pada penelitian ini akan tetap dilakukan ektraksi parameter kualitas air yang berupa Suspended Solid (SS) sebagai bukti bahwa nilai NMAE yang tidak memenuhi syarat akan berdampak pada kesalahan hasil ekstraksi. Algoritma yang digunakan untuk menghitung nilai estimasi SS adalah algoritma model Jaelani (2016).

$$
\begin{aligned}
\log (S S)=1,5212 & \left(\frac{\log R_{r s}\left(\lambda_{2}\right)}{\log R_{r s}\left(\lambda_{3}\right)}\right) \\
& -0,3698
\end{aligned}
$$

Algoritma ini akan dikembangkan untuk mencocokkan area studi yang digunakan dalam penelitian. Pembentukan algoritma baru diperoleh berdasarkan pada regresi algoritma yang terbentuk dari perbandingan antara $S S$ dan $\operatorname{Rrs}(\lambda)$ in situ. Dari perbandingan ini, akan menghasilkan persamaan regresi linier $(y=a x+b)$.

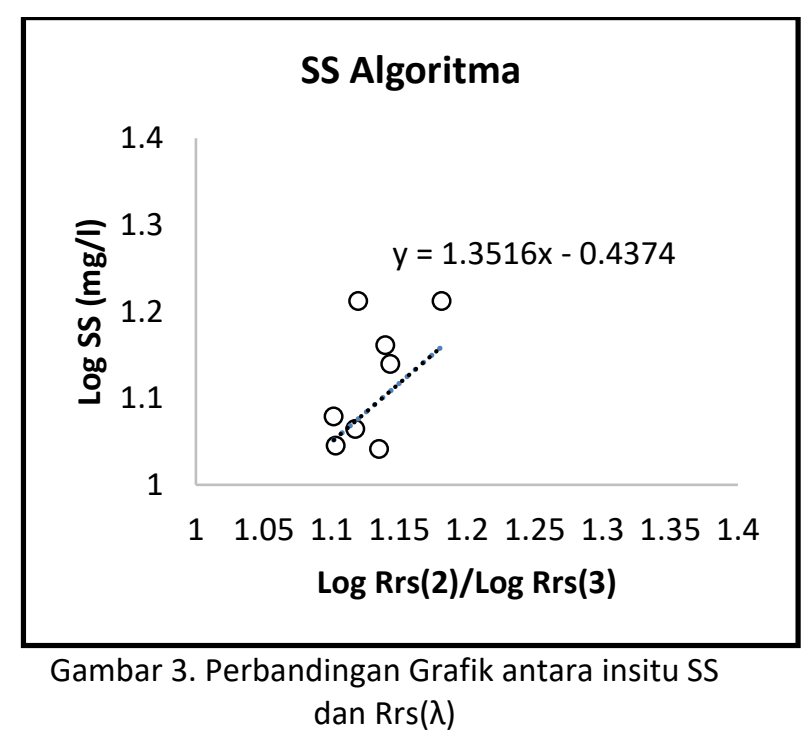

Dari hasil perhitungan ini maka didapatkan algoritma baru untuk mengekstrak konsentrasi SS pada Danau Kasumigaura yaitu sebagai berikut :

$$
\log (S S)=1,352\left(\frac{\log R_{r S}\left(\lambda_{2}\right)}{\log R_{r S}\left(\lambda_{3}\right)}\right)-0,437
$$

Dari Tabel 4 kita dapat melihat bahwa nilai estimasi SS memiliki jarak yang cukup jauh dengan SSinsitu. Hal ini karena kesalahan relatif besar (dapat dilihat pada Tabel 5), oleh karena itu dapat disimpulkan bahwa persyaratan minimum nilai NMAE harus dipenuhi ketika data penginderaan jauh akan digunakan untuk ekstraksi data parameter kualitas air sehingga data yang diperoleh sesuai dengan situasi yang sebenarnya.

Tabel 4. Perbandingan Konsentrasi SS perkiraan dan SS insitu

\begin{tabular}{cccc}
\hline \multirow{2}{*}{ Stasiun } & \multicolumn{3}{c}{ Konsetrasi SS (mg/l) } \\
\cline { 2 - 4 } & Insitu & SR & 6SV \\
\hline 1A & 11 & 11,012 & 8,440 \\
2A & 11,6 & 10,631 & 8,334 \\
3A & 12 & 10,385 & 8,296 \\
4A & 16,3 & 10,468 & 8,412 \\
5A & 11,1 & 10,224 & 8,345 \\
1B & 13,8 & 11,292 & 22,200 \\
2B & 14,5 & 11,191 & 16,750 \\
3B & 16,3 & 11,087 & 28,611 \\
4B & 9,8 & 10,090 & 15,523 \\
5B & 9,4 & 9,311 & 10,580 \\
\hline
\end{tabular}


Tabel 5. Hasil perhitungan $\mathrm{R}^{2}$, RMSE, dan NMAE dari SS

\begin{tabular}{cccc}
\hline $\begin{array}{c}\text { Metode } \\
\text { koreksi }\end{array}$ & $\mathbf{( R}^{\mathbf{2})}$ & NMAE (\%) & $\begin{array}{c}\text { RMSE } \\
(\mathbf{m g} / \mathbf{l})\end{array}$ \\
\hline 6SV & 0,255 & 37,836 & 6,017 \\
SR & 0,409 & 14,246 & 2,878 \\
\hline
\end{tabular}

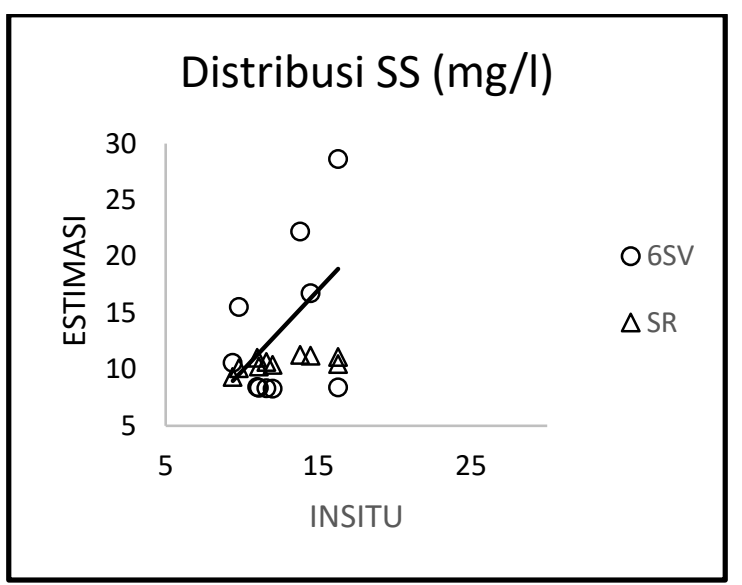

Gambar 4. Grafik Distribusi SS antara SSEstimasi dan Insitu

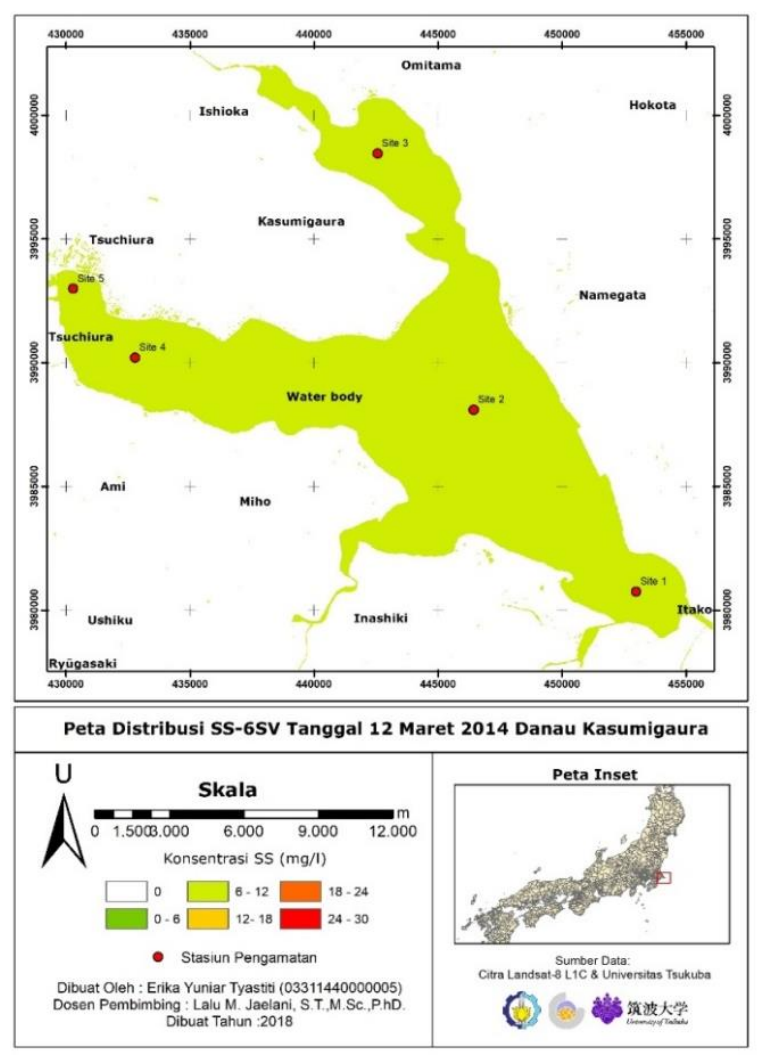

Gambar 5. Peta Distribusi SS-6SV Tanggal 12 Maret 2014

Perubahan nilai SS dari tiap citra dapat dilihat pata peta persebaran SS Gambar 5 dan
6. Peta distribusi SS dibagi menjadi 6 kelas, dengan rentang warna dari hijau ke merah sedangkan untuk hitam adalah daerah daratan. Pada citra hasil koreksi metode 6SV tanggal 12 Maret 2014 ini memiliki distribusi SS rata-rata pada $\geq 6 \mathrm{mg} / \mathrm{l}$, sehingga memiliki warna hijau yang dominan namun dibeberapa sisi terdapat warna merah yang menggambarkan adanya konsentrasi SS yang lebih tinggi. Sedangkan pada citra tanggal 27 Oktober 2016 distribusi SS sangat tinggi yaitu berkisar antara $12-30 \mathrm{mg} / \mathrm{l}$ sehingga didominasi oleh warna kuning dan merah. nilai SS terbesar berada di sisi utara danau, dan pantai danau. Ini karena danau utara adalah muara sungai Koiso, yang menyebabkan distribusi besar partikel yang mengalir dari daratan melalui sungai ke danau.

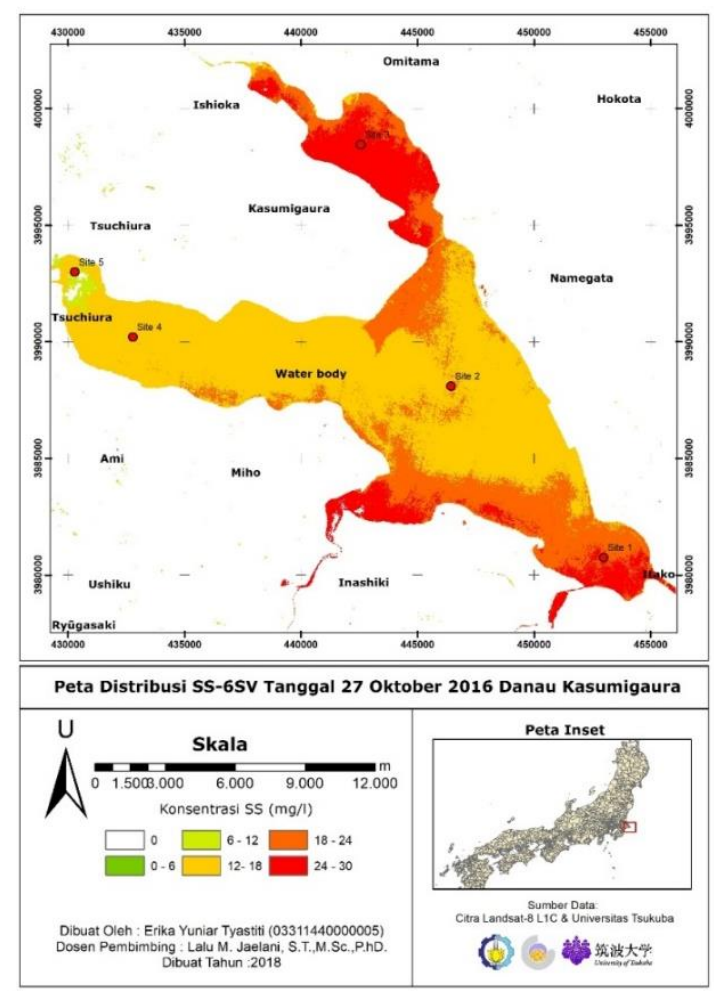

Gambar 6. Peta Distribusi SS-6SV Tanggal 27 Oktober 2016

Lokasi muara sungai sangat dipengaruhi oleh aktivitas nelayan dan aktivitas hidrooseanografi yang tinggi membuat muara sungai telah meningkatkan nilai kekeruhan karena nilai SS yang tinggi.Namun hasil ini tidak $100 \%$ akurat karena pada citra hasil koreksi atmosfer metode 6SV ini memiliki nilai perhitungan 
NMAE yang cukup besar yaitu 140,263\% pada data $\operatorname{Rrs}(\lambda)$ nya dan perbedaan sebesar 6,017 $\mathrm{mg} / \mathrm{l}$ terhadap data SS insitu.

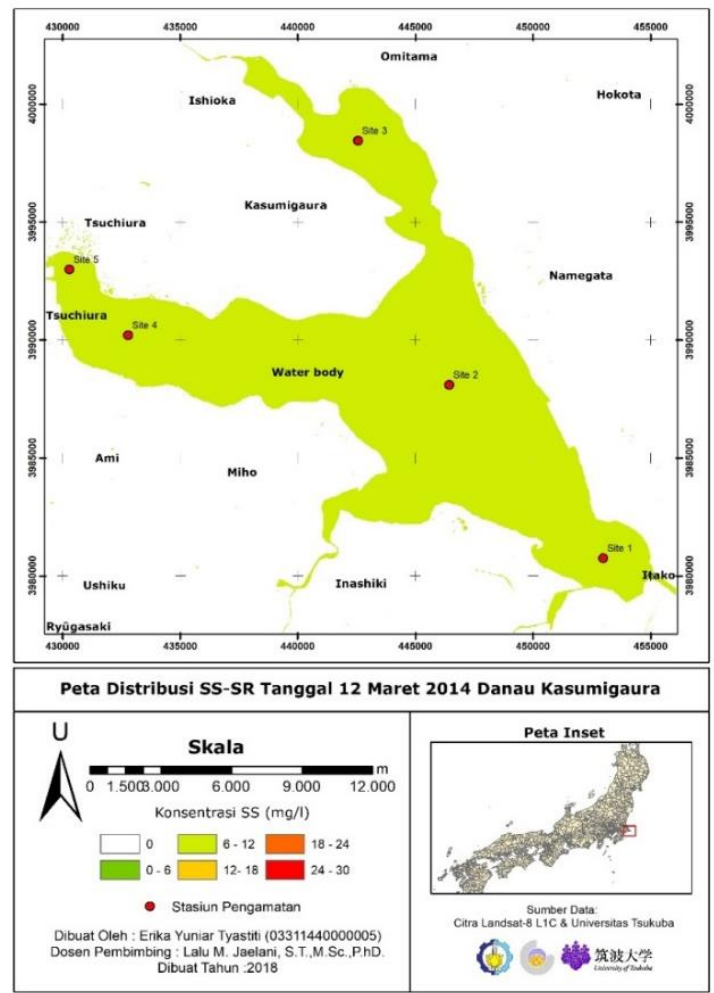

Gambar 7. Peta Distribusi SS-SR Tanggal 12 Maret 2014

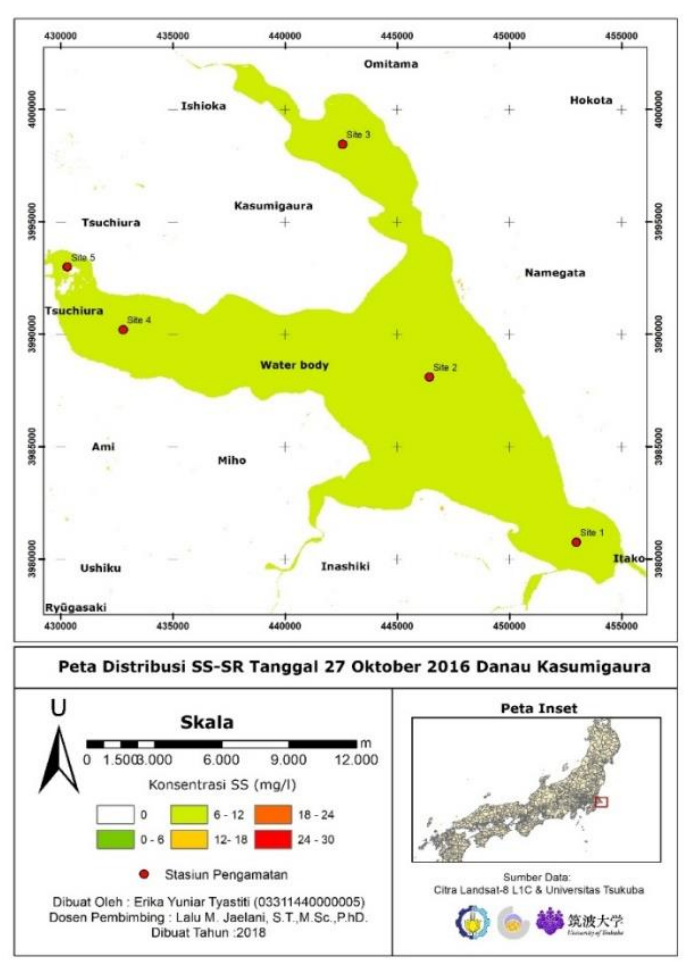

Gambar 8. Peta Distribusi SS-SR Tanggal 27 Oktober 2016
Pada kedua citra Landsat-8 hasil koreksi atmosfer langsung dari USGS ini memiliki kosnsentrasi distribusi SSyang hampir sama diseluruh bagian dari danau yang berkisar antara 6-12 mg/l. Dimana, dapat dikatakan bahwa dalam rentang 2 tahun yaitu 2014 hingga 2016 konsentrasi distribusi SStidak mengalami perubahan yang signifikan bahkan sama (tetap). Namun hasil ini tidak $100 \%$ akurat karena pada citra Landsat- 8 hasil koreksi atmosfer langsung dari USGS ini memiliki nilai perhitungan NMAE yang cukup besar yaitu $140,062 \%$ pada data $\operatorname{Rrs}(\lambda)$ nya dan perbedaan sebesar $2,878 \mathrm{mg} / \mathrm{l}$ terhadap data SS insitu.

\section{KESIMPULAN}

Berdasarkan hasil penelitian yang telah dilakukan terdapat beberapa hal yang dapat disimpulkan dalam penelitian ini, yaitu :

1. Perbandingan nilai $\operatorname{Rrs}(\lambda)-6 \mathrm{SV}$ dan $\operatorname{Rrs}(\lambda)$ $S R$ dapat dilihat dari korelasinya $\left(R^{2}\right)$ yaitu $\operatorname{Rrs}(\lambda)$-L memiliki korelasi lebih tinggi yaitu sebesar 0,926 dibandingkan dengan Rrs $(\lambda)$-6SV yang hanya 0,123 serta besarnya NMAE serta RMSE yang dihasilkan $\operatorname{Rrs}(\lambda)$-6SV dan $\operatorname{Rrs}(\lambda)$-SR ini secara berturut-turut adalah $140,262 \%$; 0,012 dan 140,061\%; 0,008.

2. Data Landsat-8 Surface ReflectanceBELUM LAYAK digunakan secara langsung untuk mengekstrak parameter kualitas air dari data penginderaan jauh karena nilai NMAE yang dihasilkan masih di bawah syarat minimum (30\%), pada penelitian ini NMAE yang dihasilkan adalah sebesar $140,061 \%$.

3. Nilai SS estimasi baik SS-6SV maupun SSSR memiliki selisih yang jauh dengan SSinsitu. Hal tersebut dikarenakan RMSE yang dihasilkan relatif besar yaitu 6,017 untuk SS-6SV dan 2,877 untuk SS-SR. Hal tersebut juga dilatarbelakangi oleh data $\operatorname{Rrs}(\lambda)$ yang digunakan untuk mengekstrak informasi SS tidak memenuhi syarat karena memiliki nilai NMAE yang masih dibawah syarat minimum. 


\section{UCAPAN TERIMA KASIH}

Penulis E.Y.T mengucapkan terima kasih kepada Bapak Lalu M. Jaelani, S.T., M.Sc., Ph.D. selaku dosen pembimbing yang telah banyak membantu dalam penelitian ini sehingga penelitian ini dapat berjalan dengan lancar.

\section{DAFTAR PUSTAKA}

Han, Luoheng, Karen JJ. 2005. Estimating and mapping chlorophyll- a concentration in Pensacola Bay, Florida using Landsat ETM+ data. International Journal of Remote Sensing, Vol. 26, No. 33, 5245-5254.

Jaelani, L.M. 2015. Uji Akurasi Produk ReflektanPermukaan Landsat Menggunakan Data In Situ Di Danau Kasumigaura, Jepang. Teknik Geomatika ITS. Surabaya.

Lillesand, T. M. dan F. W. Kiefer. 1990. Penginderaan Jauh dan Interpretasi Citra in R. Dulbahri (Ed). Gajah Mada University Press. Yogyakarta. $725 \mathrm{~h}$.

Souma, Kunika. 2016. Efforts to Improve Water Quality in Lake Kasumigaura by The Ibaraki Prefectural Government. Pemerintahan Ibaraki, Jepang 